Die F. Fürftenthergifdse Dumainenfanglei, ber zwei forftidje Mitglieder beigegeben find, ift die leitende und überwadende $B_{e}=$ Görde, ifre find Die Birthjaraftzbeamten, welde Den Titel Forft $=$ verwal ter fübren, unmittelfar untergeoronet, es befteten alfo feine örtliden Controlbehörden mefr.

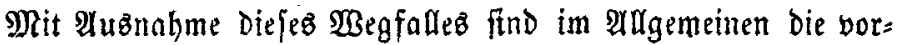
liegenden Dienftuoridriften Den bei Der Badifden StaatBforftyer=

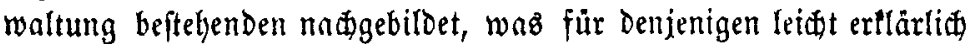

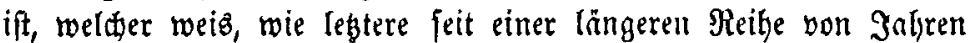

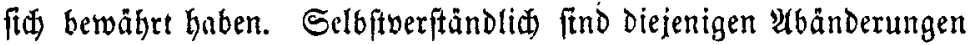
Dabei getroffen, weldje bei Dem befondern Eigentfumgerbältnis in Der $\mathfrak{R a t u r}$ Der Sndie liegen.

Für bie Befízer gröferer $\mathfrak{B a l b u n g e n , ~ w e l đ e ~ e i n ~ e i g e t r e b ~ F o r f t = ~}$ perfonal haben, Dürften Diefe Borjdriften wohl febr beadtensmerth fein, Da fie in jeder Şinfitht auf Der Şöbe Der Zeit fteben, was man nidt jeder ftandeaberrliden zorftoerwaltung nadjühmen fann.

Ber etwa einen Streunubungäplan bermiffen follte, Dem twollen wir bemerfen, Daß in Den $\mathfrak{F}$. Fủrftenbergifđen $\mathfrak{B a l}$ a ungen feine Streunugung frattindet.

\title{
№. 26.
}

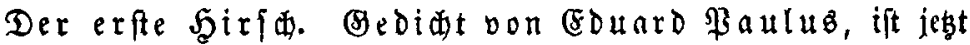
mit Slluftrationen verjeken auf einem größzern Blatte in Der (E.

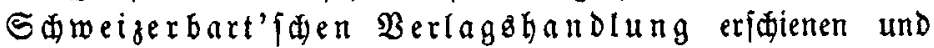

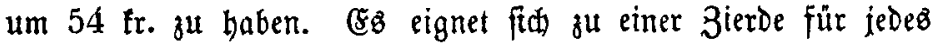

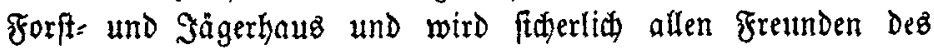

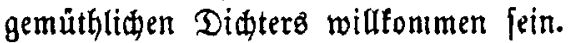

